\title{
REGIONAL POLICY AND REGIONAL DEVELOPMENT: A CASE STUDY OF CHINA'S WESTERN DEVELOPMENT STRATEGY
}

\author{
Zheng $\mathrm{Lu}^{\mathrm{l}}$ \\ Xiang Deng ${ }^{2}$
}

\begin{abstract}
China's Western Development Strategy (WDS) has been carried out since 1999 with remarkable achievements, whereby Western China also experienced a rapid and stable development during the past decade. This paper analyzes policy actions and effects of WDS. The findings indicate that Western China's economic development has experienced a dramatic reversion after implementation of WDS, which to a certain extent, proves that WDS has played a significant role in promoting western regions' development. This paper also reveals some key constraints on Western China's economic development and then offers a set of policy ideas for the next stage of Western development.
\end{abstract}

Keywords: Western Development Strategy, Regional Policy, Policy effects, Western China

JEL Codes: E62, R11, R58

\section{Introduction}

Since 1949 China has adjusted its regional development strategy three times. The first stage (1949-1978) is known as Balanced Development. Its major objective was to seek an absolutely balanced development. The second stage (1979-1991) was Unbalanced Development with a major objective of preferentially developing regions with special advantages. The third stage (1992-present) is known as Coordinated Development, whose major objectives are to promote the development of underdeveloped regions and reduce regional disparities.

In the Balanced Development stage, national investment tended to favor central and western regions in this stage. During this stage two "GO-WEST" campaigns were implemented. As a result, the hinterland economy developed quickly, but such achievements were obtained at the cost of an overall loss of economic efficiency in that a large number of resources were compulsorily allocated to western regions. In the Unbalanced Development Stage, preferential policies such as investment, reform and opening-up policies were implemented exclusively in certain eastern coastal regions. In this stage, the overall gross economy, especially the economy in eastern regions grew rapidly. However, only regions that were granted preferential policies obtained benefits from this open economy. In 1991 and 1992 Coordinated Development Strategy and building up of the market economy were conducted successively. The "opening-up" drive gradually spreads to hinterland which not only enabled hinterland to obtain equivalent preferential policy supports but it also put hinterland and coastal regions in an equal competitive environment (Gao and Tong, 2008). However, the policy of giving priority to coastal areas in 1980s actually has helped eastern regions establish to establish an advantage that other regions cannot match. The positive effects of opening-up policy in central and western regions were much lower than those in eastern regions (Guo, Lu and Gan, 2002) and regional disparities were actually exacerbated sharply from the early 1990s (Démurger, 2001; Fan and Sun, 2008; Fan, Kanbur and Zhang, 2010).

\footnotetext{
${ }^{1}$ School of Economics, Sichuan University, Chengdu 610064, P.R. China, e-mail: zlu@ scu.edu.cn

2 School of Economics, Sichuan University, Chengdu 610064, P.R. China, e-mail: dengxiang@scu.edu.cn

Note: An earlier version (title: China's Western Development Strategy: Policies, Effects and Prospects) of the paper was posted on MPRA, No.35201.
} 
It was against such a background that China's central government proposed the Western Development Strategy (WDS) in 1999 to accelerate development in western regions and reduce regional disparities. The State Council released a set of policy measures in October 2000, marking the formal implementation of WDS. By 2010 WDS had been in effect for 10 years ${ }^{3}$. What happened during this decade? What was the effect of WDS and what should be done in the next stage? Answers to such questions are particularly important for next round of western development. This paper will focus on these points following logic of "Policies-Effects-Problems-Suggestions". It will primarily analyze policy actions, economic outcomes and problems of western economic development in the first 10-years of WDS and then put forward some proposals ${ }^{4}$.

The remainder of this paper is organized as follows: Part 2 reviews policies and corresponding actions; Part 3 analyzes the economic outcomes in the first 10-years development of western regions; Part 4 discusses key constraints on Western China's economic development; and the last part is conclusions and proposals.

\section{Policy Actions of Western Development Strategy}

Following the policy framework released by the State Council, relevant departments of central and local governments also issued some specific policies. These policies constitute a relatively complete policy system covering numerous fields of Western China's economic and social development. Here we will focus on major policy instruments and actions taken under WDS.

\section{Fiscal Transfers and Tax Preference}

Intergovernmental Fiscal Transfers play an important role in WDS with the central government enhancing its transfers to local governments in Western China. Between 2000 and 2005, a gradual increase scale general transfer payments to local governments in Western China accumulated to RMB404.4 billion, accounting for 52.6 percent of the total (Ye, 2006). This increase of total transfers (including general transfers and special transfers) also reflected that fiscal transfers of the central government tended to go disproportionately to western regions. In 1999, $29.01 \%$ of the central government's fiscal transfers were allocated to Western China while in 2010 this ratio reached $39.42 \%$, indicating a significant rising trend, especially after the implementation of WDS.

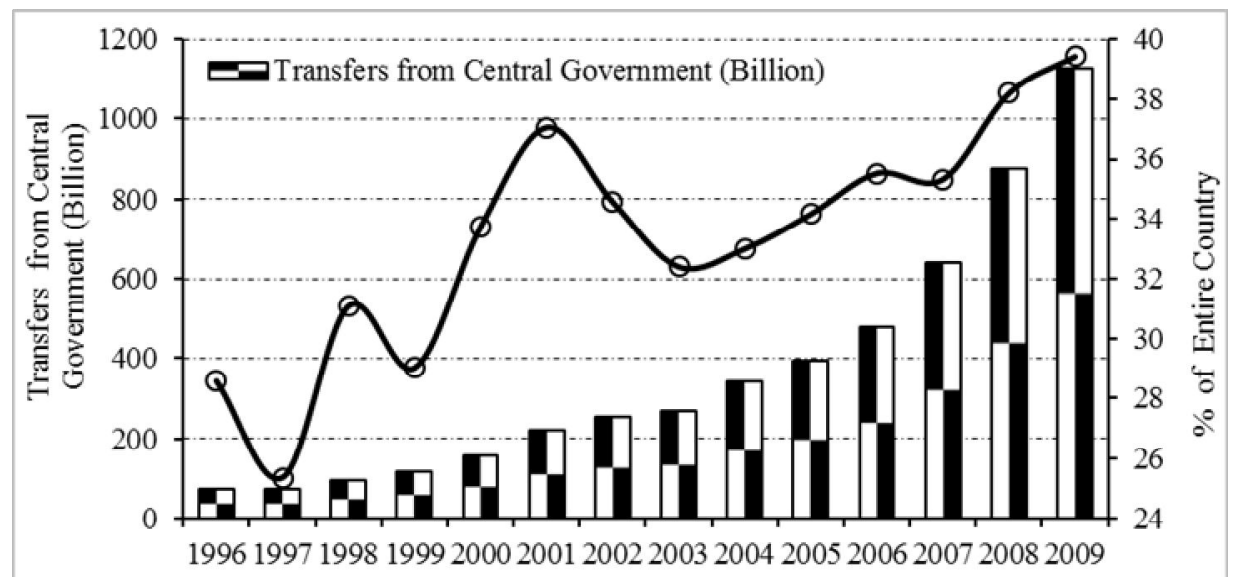

Note: \% of Entire Country=Transfers from Central Government of Western China / Transfers to Local Government of Central Government. The data are calculated by authors based on the statistical data from various issues of the Finance Year Book of China.

Figure no.1.- Transfers from the Central Government of Western China

\footnotetext{
${ }^{3} \mathrm{CPC}$ Central Committee and State Council have promulgated a new policy paper which further improved and intensified policy measures in June 2010, key preferential policies validity was extended 10 years further.

${ }^{4}$ Western regions or Western China refers to 12 provincial administrative regions including Inner Mongolia, Guangxi, Chongqing, Sichuan, Guizhou, Yunnan, Tibet, Shaanxi, Gansu, Qinghai, Ningxia and Xinjiang. Moreover, China mainland is divided into four parts in terms of the official economic regionalization at present. Besides Western China, other three regions are Eastern China (includes Beijing, Tianjin, Hebei, Shanghai, Jiangsu, Zhejiang, Fujian, Guangdong and Hainan), Central China (includes Shanxi, Anhui, Jiangxi, Henan, Hubei and Hunan) and Northeastern China (includes Liaoning, Jilin and Heilongjiang). This paper will follow this kind of classification.
} 
Tax reduction and exemption are the most import preferential policies of WDS. Enterprise income tax reduction is of primary importance while the reduction or exemption of business tax, value added tax and resource tax, etc., are supplementary measures. Generally, preferential tax policies of WDS usually include:

- For domestic and foreign-funded enterprises in Western China which belong to the category encouraged by the state enjoy $15 \%$ income tax rate;

- For new enterprises of transportation, power, water conservancy, postal service, radio and television in Western China, these domestic enterprises' income tax can be exempted in the first two years and reduced by half in the subsequent three years from the start of operation (known as the policy of "two-year exemption and three-year half deduction"). Foreign-funded enterprises can also benefit from the same policy if their operating period exceeds ten years;

- For imported equipment used in the projects encouraged in western areas or in local competitive industries, tariffs and import value added tax can be exempted (except for commodities otherwise defined by the state, to which such policies are not applicable);

- For pilot rural credit cooperatives (RCC) in Western China, income tax was exempted from Jan. $1^{\text {st }}, 2003$ to the end of 2005; and

- For key infrastructure construction projects, the government made corresponding special preferential tax policies. For example, during the construction of Qinghai-Tibet Railway almost all kinds of taxes generated by the project were exempted.

\section{National Investment}

Since 2000 the distribution of national key projects sponsored by national fiscal funds and national bonds tended to favor western regions, where in the past decade the commencement of 143 key projects involved a total investment figure of over RMB2874.2 billion. Such projects impact various areas of the economy such as infrastructure construction, ecological environmental protection, rural development, education, medical treatment, public health, etc.

Table no.1

Key Projects Investment of Western Development by Year

\begin{tabular}{|c|c|c|l|}
\hline $\begin{array}{c}\text { Commencement } \\
\text { Year }\end{array}$ & $\begin{array}{c}\text { Number of } \\
\text { Key Projects }\end{array}$ & $\begin{array}{c}\text { Investment } \\
\text { (RMB Billion) }\end{array}$ & \multicolumn{1}{|c|}{ Major Areas of Investment } \\
\hline 2000 & 10 & $>100$ & $\begin{array}{l}\text { Airport Construction, Infrastructure Construction of } \\
\text { Western Universities, "Returning Grain Plots to Forests" } \\
\text { Project }\end{array}$ \\
\hline 2001 & 12 & $>200$ & $\begin{array}{l}\text { Qinghai-Tibet Railway, West-East Electricity } \\
\text { Transmission Project, Highway Construction, "Return } \\
\text { Grain Plots to Forests" Project, Urban Infrastructure } \\
\text { Construction }\end{array}$ \\
\hline 2002 & 14 & $>330$ & $\begin{array}{l}\text { West-East Gas Project I, Airport Construction, Water } \\
\text { Pollution Control of Three Gorges Reservoir Area, } \\
\text { "Returning Grain Plots to Forests" Project }\end{array}$ \\
\hline 2003 & 14 & $\begin{array}{l}\text { Urban Infrastructure of Tibet and Xinjiang Municipality, } \\
\text { "Returning Farmland to Forests" Project, "Returning } \\
\text { Grazing Land to Grassland" Project, Rural Drinking } \\
\text { Water Project, Rural Energy Project, Ecological } \\
\text { Immigration and Resettlement }\end{array}$ \\
\hline 2004 & 10 & $>130$ & $\begin{array}{l}\text { Arterial highway construction, Regional Airports } \\
\text { Construction, Mining Engineering, Rural Infrastructure } \\
\text { Construction }\end{array}$ \\
\hline \multirow{2}{*}{10} & $>130$ & $\begin{array}{l}\text { Railway Construction, Airport Construction, Mining } \\
\text { Engineering Infrastructure Construction }\end{array}$ \\
\hline
\end{tabular}




\begin{tabular}{|c|c|c|l|}
\hline 2006 & 12 & 165.4 & $\begin{array}{l}\text { Highway construction, Airport Construction, Mining } \\
\text { Engineering Infrastructure Construction, Hydropower } \\
\text { Station Construction }\end{array}$ \\
\hline 2007 & 10 & 151.6 & $\begin{array}{l}\text { Regional Airports Construction, Social Programs } \\
\text { (Education, Public Health and so forth) }\end{array}$ \\
\hline 2008 & 10 & 436.1 & $\begin{array}{l}\text { Highway Construction, Rural Road Construction and } \\
\text { Reconstruction, Airports Construction, West-East Gas } \\
\text { Project II }\end{array}$ \\
\hline 2009 & 18 & 468.9 & $\begin{array}{l}\text { Railway Construction, Highway Construction Airports } \\
\text { Construction、 Water Infrastructure Construction、Power } \\
\text { Infrastructure Construction }\end{array}$ \\
\hline 2010 & 23 & 682.2 & $\begin{array}{l}\text { Railway Construction, Airport Construction, Water and } \\
\text { Power infrastructure Construction }\end{array}$ \\
\hline $2000-2010$ Total & 143 & $>2874.2$ & \multicolumn{1}{|c}{} \\
\hline
\end{tabular}

Note: Collected and processed by authors based on various bulletins of the Department of Western Region Development at National Development and Reform Commission.

From another perspective, the increased state budget for investment in fixed assets also reflects the important role of government investment. From 2001 to 2010, average annual growth rate of state budget for investment in fixed assets in Western China was 30.76\%, which was much greater than that in eastern, central and northeastern regions. The state budget share for Western China also increased annually and was much greater than that of other regions. National bonds also played a significant role in WDS: about $40 \%$ of long-term national bonds were invested in western regions each year. According to statistical data, the central government assigned RMB341.4 billion bond-financed projects fund to western regions from 2000 to 2005 (45.8\% of total assigned funds). The share of long-term national construction bonds in western regions exceeded $40 \%$ after WDS. Such bonds were primarily invested in the construction and improvement of infrastructure (Zhu, 2004; SIC, 2005; Ye, 2006). Moreover, since 2009, local governments can apply to issue local bonds. Provinces in Western China issued a total of RMB75.0 billion local bonds in 2009.

Table no. 2

Regional Distribution of State Budget in Funds for Investment in Fixed Assets

\begin{tabular}{|c|c|c|c|c|c|c|}
\hline \multirow{2}{*}{ Year } & \multirow{2}{*}{$\begin{array}{c}\text { National Total } \\
\text { (RMB Billion) }\end{array}$} & $\begin{array}{c}\text { Eastern } \\
\text { China }\end{array}$ & $\begin{array}{c}\text { Central } \\
\text { China }\end{array}$ & $\begin{array}{c}\text { Western } \\
\text { China }\end{array}$ & $\begin{array}{c}\text { Northeastern } \\
\text { China }\end{array}$ & $\begin{array}{c}\text { Not Classified By } \\
\text { Region }\end{array}$ \\
\hline 2000 & 159.41 & 25.56 & 20.64 & 25.93 & 7.25 & 20.62 \\
\hline 2001 & 205.23 & 24.46 & 18.39 & 25.61 & 8.82 & 22.71 \\
\hline 2002 & 253.36 & 17.80 & 17.14 & 34.23 & 6.84 & 23.99 \\
\hline 2003 & 210.32 & 24.40 & 19.41 & 38.68 & 7.92 & 9.58 \\
\hline 2004 & 325.50 & 24.70 & 20.03 & 33.61 & 7.61 & 14.05 \\
\hline 2005 & 415.43 & 24.01 & 19.86 & 32.84 & 9.01 & 14.28 \\
\hline 2006 & 467.20 & 21.06 & 21.82 & 33.13 & 10.15 & 13.84 \\
\hline 2007 & 585.71 & 22.17 & 24.39 & 32.12 & 11.16 & 10.16 \\
\hline 2008 & 795.48 & 23.50 & 24.50 & 33.08 & 10.24 & 8.69 \\
\hline 2009 & 1268.57 & 21.81 & 24.46 & 39.24 & 9.70 & 4.79 \\
\hline 2010 & 1467.78 & 20.64 & 23.77 & 41.15 & 8.70 & 5.74 \\
\hline
\end{tabular}

Source: Various issues of China Statistical Yearbook (China National Bureau of Statistics, various issues).

\section{Financial and Credit Support}

Capital shortage is a major constraint factor in western regions' development. In order to increase development funds for WDS, the central government and People's Bank of China (PBC) promulgated several measures to encourage financial institutions. These measures include, 
- The use of national policy banks to augment loans for western regions' development;

- The encouragement of foreign banks to establish branches in West China;

- The encouragement of private capital to participate in the construction of financial services institutions; and

- The promotion establishing and developing village banks, finance companies and rural fund cooperatives in western rural areas.

With the guidance and support of government policy, various financial institutions, especially state-owned commercial banks and policy banks increased their lending scale for western regions. By the end of 2010, the loans balance of CDB for West China reached RMB1,008.19 billion, accounting for $22.36 \%$ of its total loans, a remarkable increase compared with that in 2001 (17.78\%). The loan provided to Western China by ADBC, a major policy bank that mainly provides financial support for agriculture and rural development, reached RMB336.02 billion in 2009, also a noticeable increase of its share at the beginning of WDS. Meanwhile other major state-owned commercial banks also increased their loans in western regions in a similar manner.

Table no. 3

Loans Balance Share of Western China in Major Banks

\begin{tabular}{|c|c|c|c|c|c|c|}
\hline \multirow{2}{*}{ Year } & \multicolumn{2}{|c|}{ Policy Banks } & \multicolumn{4}{|c|}{ Four Major State-owned Commercial Banks } \\
\cline { 2 - 7 } & ADBC & CDB* & ABC & CCB & ICBC & BC \\
\hline 1999 & 18.51 & & 22.92 & 19.26 & & 12.92 \\
\hline 2000 & 18.30 & & 23.67 & 18.68 & & 12.52 \\
\hline 2001 & 18.14 & 17.87 & 23.43 & 19.06 & & 13.16 \\
\hline 2002 & 17.55 & 19.14 & 22.83 & 18.89 & & 13.62 \\
\hline 2003 & 18.09 & 21.46 & 22.27 & 18.62 & & 13.96 \\
\hline 2004 & 18.15 & 22.47 & 22.18 & 18.42 & & 13.96 \\
\hline 2005 & 19.33 & 22.01 & 22.51 & 18.53 & 14.72 & 10.08 \\
\hline 2006 & 19.61 & 22.14 & 22.15 & 16.34 & 14.69 & 10.00 \\
\hline 2007 & 21.74 & 23.24 & 21.56 & 16.22 & 15.04 & 9.86 \\
\hline 2008 & 22.36 & 21.62 & 21.23 & 16.76 & 16.02 & 10.52 \\
\hline 2009 & 23.15 & 22.33 & 21.79 & 17.00 & 16.62 & 10.50 \\
\hline 2010 & & 22.36 & 21.97 & 17.00 & 16.82 & 11.11 \\
\hline
\end{tabular}

Note: ADBC-Agriculture Development Bank of China, ABC-Agriculture Bank of China, BC-Bank of China, CCB-China Construction Bank, ICBC-Industrial \& Commercial Bank of China, CDB-China Development Bank; *CDB was transformed into a state-owned commercial bank in Dec. 2008. The data are from various issues of Almanac of China's Finance and Banking (Research Bureau of The People's Bank of China, various issues) and annual reports of banks.

\section{Channeling Policy}

Channeling policies are supplementary policy instruments. The Chinese government employed four types of guiding policies in WDS:

- Channeling investment of foreign and private capital;

- Incentive mechanisms to encourage high-level talents to work in western regions;

- Window guidance to financial institutions in order to augment loans support; and

- The encouragement of eastern developed regions to provide aids to western regions.

In 2002, the NDRC (National Development and Reform Commission) promulgated "Several Opinions on Promoting and Channeling Private Investment", which suggested that local governments vigorously support private investment in high-tech projects. The NDRC also released 'Catalogue of Priority Industries for Foreign Investment in the Central-Western Region' to channel the investment of foreign capital. In 2002 the Central Committee of the Communist Youth League of China and Ministry of Education jointly launched the "Go West College Graduates Volunteer Program", in which every year college graduates were recruited as volunteers to work in western backward areas for one to two years, mainly in the fields of education, health care and poverty 
reduction. Between 2003 and 2010 this program accumulatively recruited more than 90 thousand volunteers for service in western regions. The sponsors also encourage college students to obtain employment in western regions after graduation.

In 2002 the central government formulated and implemented a 'Ten-Year Plan for Developing Talented People in the Western Region'. The main ideas of the Plan were to help develop education in poor regions in Western China, increase and improving personnel exchanges and overall interactions between Eastern and Western China, and to dispatch outstanding functionaries from central, eastern and midland governments to work in western areas or to exchange functionaries between governments in various areas. Official data showed that in the past decade 3,528 functionaries from western local governments were assigned to work in central and eastern local governments temporarily as the means to improve their administrative ability.

\section{Interregional Mutual Aid Promotion Policy}

There are two types of interregional mutual aid promotion policies. The first one is called Hand-in-Hand Aid (HHA) or Counterpart Support policy. HHA's objective is to promote the development of a region or an industry, through the government formulation of pairing mutual aid relationship or partnership between different regions or industries based on each other's advantage. To some extent HHA policy is a compulsory measure. The central government will consider the opinions of local governments but has the final regarding in "who aids who" and "how to aid". HHA aid involves various aspects of economic and social development, such as infrastructure construction, education, industrial development, technical assistance and direct capital investment. Up to now China has implemented four large HHA programs and all beneficiaries are in Western China namely, the Three Gorges reservoir area, Tibet, Xinjiang and Earthquake Hit Areas in Sichuan province.

The second one is the East-West Interaction (EWI) policy. In accordance with market rules, economic entities from eastern regions and western regions jointly promote cross-regional flow of production factors through exercising their comparative advantages and eventually achieve the goal of optimizing national distribution of productive forces. EWI was first proposed in 2005 and the official policy was released in 2007. Although East-West interaction has always involved self-promotion and self-enforcement through market mechanisms, this policy was the first time that it was promoted by central government as an official policy. Obviously there are essential differences between HHA and EWI by definition. EWI is based on the voluntary action of eastern regions and central government mainly encourages enterprises in eastern regions to invest in western regions rather than playing a more active role.

\section{Economic Outcomes of the First Stage Development}

The achievement of WDS is reflected in various fields, such as economic development, infrastructure, education, and ecological and environmental protection. This paper just focuses on economic development and residents' income, because the most important goal of WDS is to promote economic development and reduce regional disparities.

China's economic growth was very fast after implementing the Reform and Opening-up strategy in 1978. The country began to enjoy a rapid and stable growth especially after 1992 when China started transforming its planned economy into a market one. The average annual growth rate of China's GDP reached 10.12\% between 1979 and 2010 while the Eastern, Central, Western and Northeastern areas averaged $10.79 \%, 9.98 \%, 9.57 \%$ and $8.5 \%$ respectively. Before the implementation of WDS, the economic growth of western regions was much slower than that of other regions. However, since WDS was adopted the western economy has entered a period of fast growth with an average annual growth rate of $13.58 \%$ between 2000 and 2010, exceeding the growth of Central and Northeastern China. Since 2006 Western China's economic growth has 
surpassed Eastern China resulting in the region becoming the fastest growth region of the nation. Rapid economic growth after implementation of WDS eventually led to a reversion of GDP share. In 1980s Nominal GDP share of Western China maintained around 20\%, and then reduced rapidly from early 1990s. In 2003 it dropped to $17.09 \%$. However, it began to ascend recently and reached $18.63 \%$ in 2010.

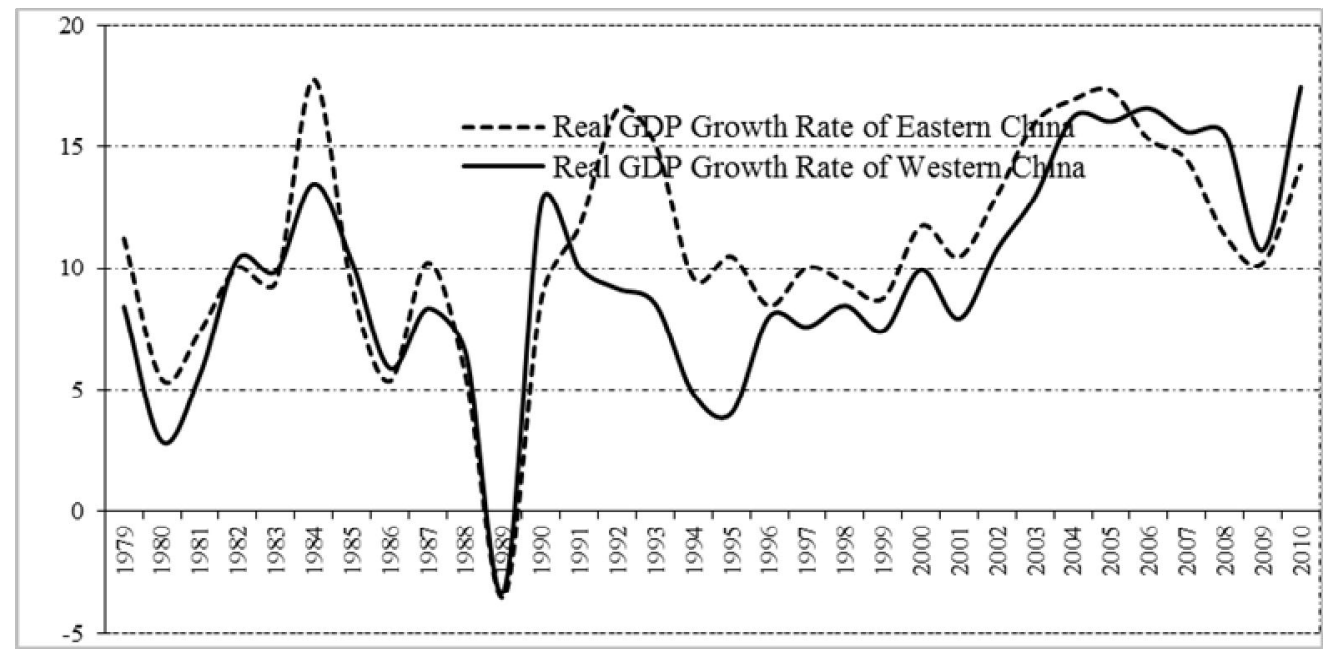

Note: Real GDP is the summation of real GDP of every provincial administrative region, that is, we calculate the real GDP of every region using local nominal GDP and CPI $(1978=100)$ at first, and then sum by region to get real GDP of Eastern, Central, Western and Northeastern China. The data are from various issues of every region's statistical yearbook especially the yearbook in 2011 which is the newest issue and the data also has been updated based on the newest National Economic Census, following indicators are from the same data sets unless noting expressly.

\section{Figure. no.2 - GDP Growth of Western China (1979-2010)}

GDP per capita of Western China grew much faster after WDS. From 1991 to 2000 the average annual growth rate of real GDP per capita was only $6.6 \%$. It rose to $13.26 \%$ from 2001 to 2010. Western China's ratio of GDP per capita to national GDP per capita ended its descending trend and started to move up after the implementation of WDS. It rose from $61.24 \%$ in 2000 to $71.28 \%$ in 2010 .

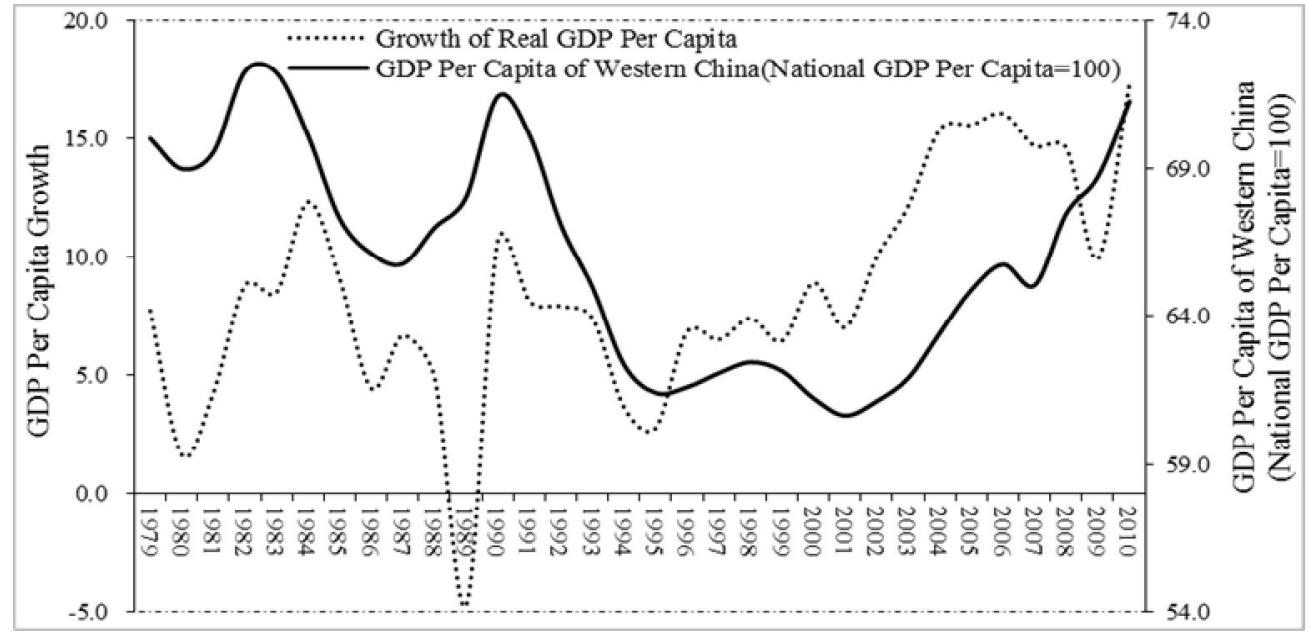

Note: $G D P p t r$ upilu $=G D P / A P$, and $A F_{t}=\left(P_{t}+P_{t-1}\right) / 2$, where $P_{t}$ is year-end population of period $t$, $A P_{t}$ is average population of period t. GDP and Real GDP of Western China are summation of every region's value.

Figure no. 3 - Real GDP Per Capita Growth of Western China(1979-2010) 
Optimization of industrial structure is an important indicator of economic development. Theoretically, during development, the share of industrial structure shows a descending trend for primary industry and an ascending trend for secondary and tertiary industry, and the share of tertiary industry will increase rapidly after economy developing to a certain level. This classic law's implications have been observed in the process of economic development in developed countries. The adjustment process of industrial structure in Western China also corresponds to this classic law. Nevertheless, the share of secondary industry dropped in 1980s and then began to rise, especially after WDS. Combining the study of industrial share with the trend of economic growth, it's easy to find that the rapid growth after WDS was primarily driven by the growth of industry (for example, mining and manufacturing) output. In 2000, the value-added share of industry in the national total was only $13.65 \%$, yet it reached $21.35 \%$ in 2010 . The value-added share of industry in local GDP also increased sharply after WDS.

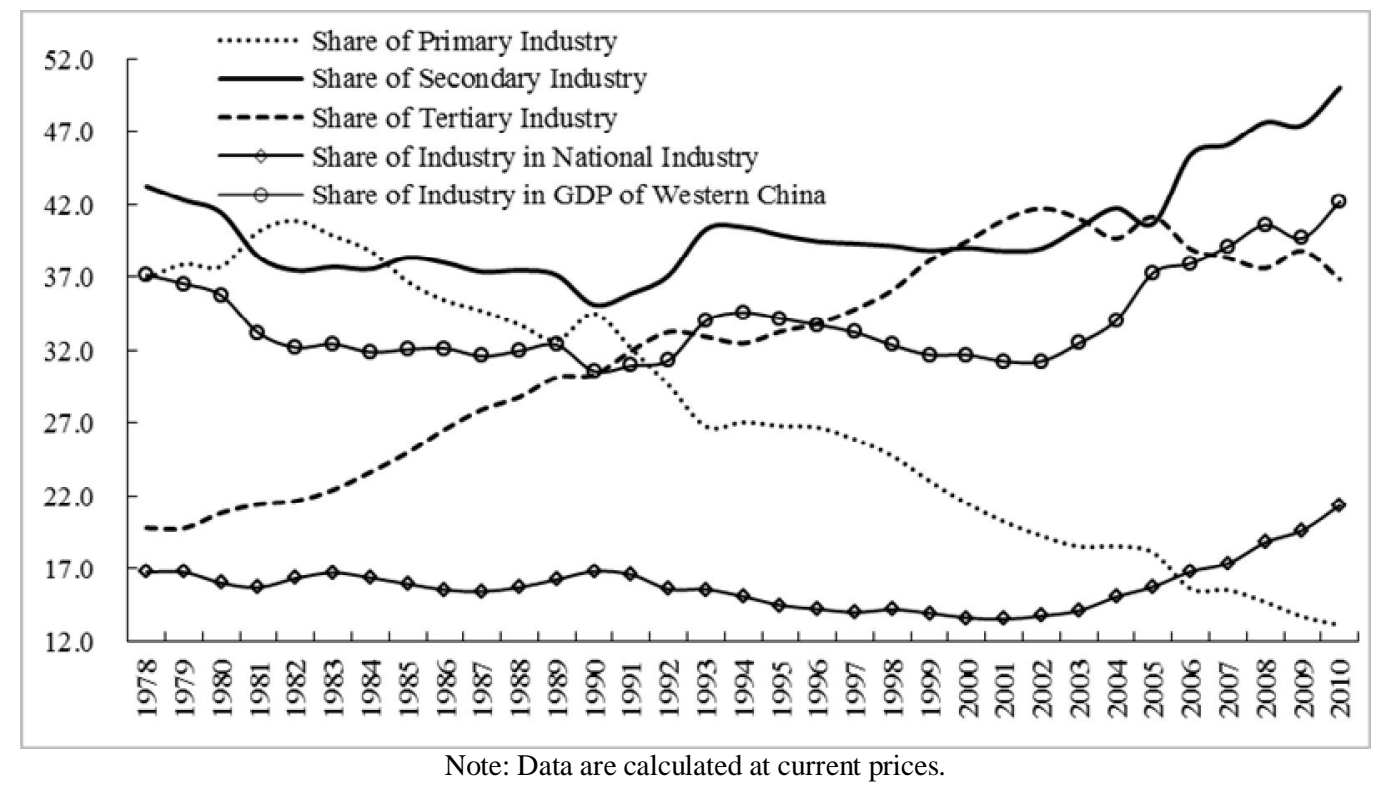

Figure no. 4 - Industrial Structure of Western China(1978-2010)

Globalization is an inevitable trend of economic development. In the past three decades international trade has became the most important driving factor of China's economic growth while Foreign Direct Investment (FDI) has also contributed heavily (Graham and Wada, 2001; Whalley and Xin, 2010). Starting in the early 1990s, the degree of dependence on foreign trade began to rise year by year. The Trade dependence index (TDI) increased to $60.26 \%$ in 2006 although recently it decreased significantly due to the global crisis starting in 2007 (46.07\% in 2010). Actual utilized FDI increased from less than US\$3.5bn in 1990 to over US\$105.7bn in 2010, an average annual growth rate of $18.6 \%$. However, Western China's foreign trade and economic cooperation lagged far behind other regions because of delays in the opening-up and backward infrastructure as well as other negative local conditions. Fortunately things began to improve significantly in recent years. TDI for Western China exceeded 10\% in 2003, rose to its highest level of $13.12 \%$ in 2007 and then dropped again to $10.61 \%$ in 2010 due to the global financial crisis. Inward FDI also grew rapidly after WDS. It was less than US\$2.0bn in 1999, merely accounting for $4.87 \%$ of the nation's total. In 2010 , it reached US\$20.81bn and the share rose to $19.68 \%$.

Rapid economic growth improved people's living conditions noticeably ${ }^{5}$. The average

\footnotetext{
${ }^{5}$ In China's official statistics, Chinese citizens are divided into urban households and rural ones, and the statistic yearbook publishes per capita income of these two groups. That's why here we just use the average value of per capita income of residents in urban and
} 
annual growth rate of real PIUH (Per Capita Disposable Income of Urban Households) in Western China was $6.27 \%$ and that of real PIRH(Per Capita Net Income of Rural Households) was only $2.91 \%$ between 1991 and 2000 . However from 2001 to 2010 they grew faster and rose to $8 \%$ and $7.57 \%$ respectively, indicating a reduced growth gap between urban and rural residents.

China's share of consumption to GDP or total expenditure is relatively very low because of its high saving rate as well as some other factors (Aziz and Cui, 2007; Guo and N'Diaye, 2010). Western China's consumption share of GDP is also very low and appears to follow the national trend. However, absolute purchasing capacity still has been strengthened, especially Western China's share of TRSCG (total retail sales of consumer goods) in the nation's total reversed after WDS. Its share was $19.82 \%$ in 1990 , dropped to $16.34 \%$ in 2003 , and then increased yearly reaching $17.41 \%$ in 2010 . Proportion of food consumption to total consumption also declined substantially. Western China's urban and rural Engel coefficients (regional mean) were respectively, $54.7 \%$ and $62.4 \%$ in $1990,42 \%$ and $58.3 \%$ in $1999,38.3 \%$ and $43.7 \%$ in 2010 . We find that the urban Engel coefficient dropped $12.7 \%$ from 1990 to 1999 and 3.6 \% from 1999 to 2010, while rural Engel coefficient dropped $4.1 \%$ and $14.5 \%$ in corresponding periods. These changes indicated that the rural living level was improved substantially after WDS. Moreover, western rural poverty statistics show significant improvement. In 2000 the poverty incidence rate was $20.8 \%$ for western rural region and in 2009 it dropped to 237.2 million and $8.3 \%$ (RSD, various versions).

\section{Key Constraints on Western China's Economic Development}

The analysis above reveals that western development strategies resulted in great achievements over the past decade. However various problems have also surfaced that definitely must be considered as serious constraints on future economic development.

\section{Intraregional Disparities and Growth Pole Development}

In recent years an exciting aspect of China's economic development is that China's interregional disparities are now following a declining trend (Liu and Zhang, 2007; Fan and Sun, 2008; Fan, Kanbur and Zhang, 2010). Unfortunately, this development is not the case for Western China as the region's intraregional disparities have enlarged significantly after WDS. The Theil index based on real GDP per capita of western regions rose from 0.031 in 2000 to 0.065 in 2010 . This increase in inequality raises questions as to whether a uniform development strategy to western regions was more effective some sub-regions than others. Western China includes 12 provinces and regions distributed in south, north, southwestern and northwestern areas where there exist enormous natural, geographical and economic differences as well as different comparative advantages.

Another type of disparity to examine is urban-rural income disparities. Urban areas and their surrounding areas develop much faster than remote rural areas. Thus, the development gap between urban and rural areas continued to widening in the past decade, and such gaps in Western China are much larger than on the national level. Although uniform regional policy should not be identified as the only factor resulting in an enlarging of intraregional disparities in Western China, diversified policies meeting local conditions could indeed contribute to preventing further widening of such disparities.

rural areas to study the income level in Western China. 
Although the central government successfully implemented several key projects to promote rural development after WDS, the western rural development situation is still very grim. In 2009 Western China's rural population accounted for over 30\% of the nation's total rural population and over $60 \%$ of the total population in Western China. While PIRH (Per Capita Net Income of Rural Households) in Western China is only $53.3 \%$ of that in Eastern China, 55.6\% of income is from household operations. Incomes from wages, salaries and properties are very low ${ }^{6}$. Moreover, $60 \%$ of China's total rural poverty population is located in Western China, and the poverty incidence rate and poverty intensity are also much higher than those rates in other regions (RSD, 2010).

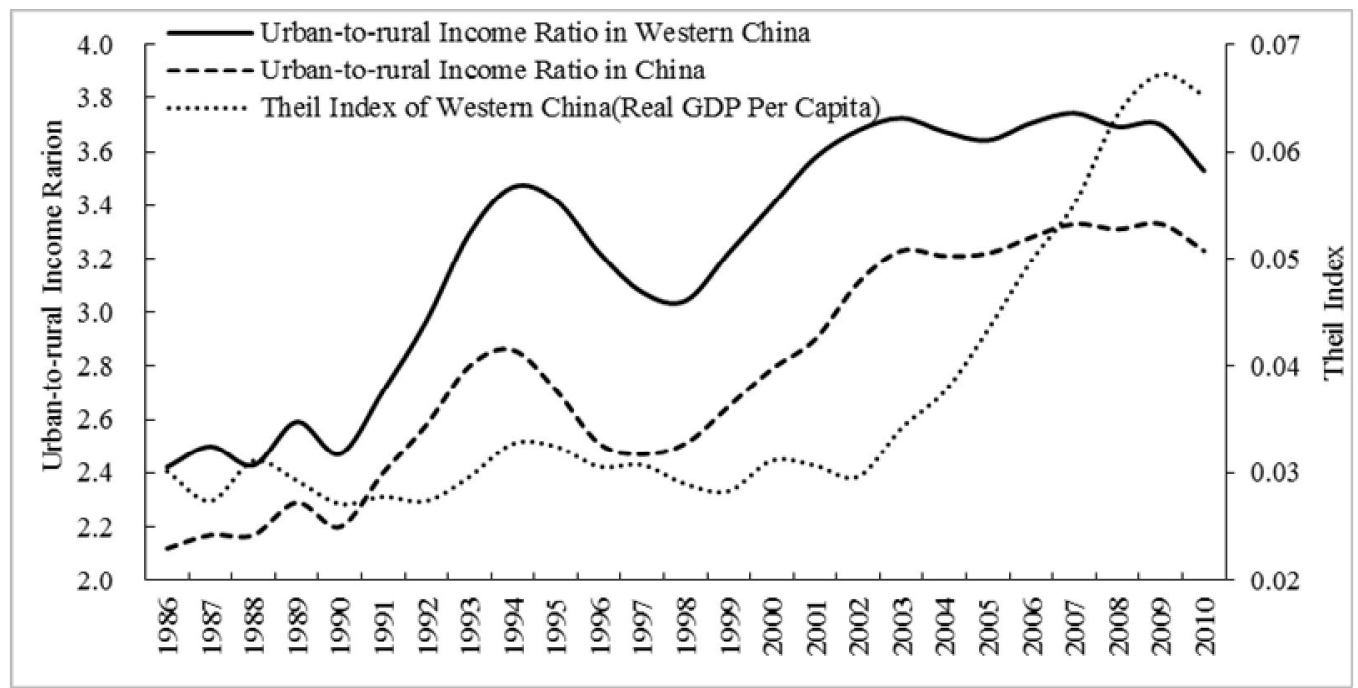

Note: Urban-to-rural Income Ratio $=\mathbf{U} / \mathbf{R}$, where $\mathbf{U}$ is Per Capita Annual Disposable Income of Urban Households and $\mathbf{R}$ is Per Capita Annual Net Income of Rural Households. Urban-to-rural Income Ratio and Theil index are calculated by author based on income and regional GDP per capita of Western China, the data are from various issues of every region's statistic yearbooks.

Figure no.5. - Regional and Urban-Rural Income Disparities in Western China

Since the 1980s, China has been using Growth Pole Theory (GPT) to guide the economic development of eastern regions, and finally built three "growth poles", the Pearl River Delta, the Yangtze River Delta and the Beijing-Tianjin-Tangshan areas. The Rapid development and positive driving effect on surrounding areas of these poles demonstrated the effectiveness of this practice. As a result of thins success, fostering regional growth poles became an imported strategy of the Western and Central China's development. Up to the present date, the central government has approved the Pan-Beibu Gulf Economic Zone (2008), the Guanzhong-Tianshui Economic Zone (2009) and the Chengdu-Chongqing Economic Zone (2011) as three national level growth poles. They are respectively located in the northern, central and southern regions of Western China. Empirical studies also show that there exist spread-backwash effects in Western and Central China (Ke and Feser, 2010; Ke, 2010).

However, GPT states that there exist two opposite effects, polarization and spreading. Thus whether an economy experiences a balance development depends on the strength of polarization effect and the strength of spreading effect. Therefore, when the growth pole is still in the stage of self-reinforcing development, the polarization effect may be stronger than the spreading effect and regional disparities as well as urban-rural disparities will increase. In the current stage of Western China's economic development, the problem may be that it still does not form a dominant growth

\footnotetext{
${ }^{6}$ Ratios are calculated by author based on the data from China Population and Employment Statistics Yearbook (China National Bureau of Statistics, 2010) and China Statistical Yearbook (China National Bureau of Statistics, 2010).
} 
pole whose spreading effect is stronger than polarization effect. These three national level growth poles require more time to strengthen and deliver more of the spreading effects.

\section{Capital Shortage and Outflows}

Capital shortage is a key factor restricting the western regions' development and this shortage will probably continue for a long time. Development capital of western regions still depends a great deal on funds from government policy and indirect financing. As for the structure of investment in fixed assets, the share of capital from national policy assignment and loans in Western China is much larger than that in other regions, while the share of foreign and self-pooled funds is relatively lower. Due to a lower return rate of investment and a less attractive investment environment, western regions have difficulty attracting enough foreign capital, eastern regions' capital and private capital to invest in local industries.

Moreover, there are serious capital outflows in Western China, which is definitely destructive in a region suffering from a capital shortage. According to statistical data from various local statistical yearbooks, Western China's ratio of loans to deposits decreased year by year in the past two decades, declining from $125.37 \%$ in 1990 to $69.55 \%$ in 2010 . For specific regions such as Tibet $(23.27 \%)$, Xinjiang (56.06\%) and Shanxi (60.85\%), the ratios were much lower than average level for western regions. Fortunately, governments have made efforts to promote trade and investment as well as to improve investment environment. However, the continuing problems of capital shortage and outflows indicate that further efforts and more efficient solutions are required.

Human capital shortage and brain drain is another aspect of capital shortage. In recent years, the central and local governments heavily promoted education and personnel training. Thanks to the gradually increased education input and the promotion of policies for finding talents such as "Go west", the stock of human capital of Western China has increased significantly. However, similar to the situation with investment capital, western regions still suffer from a shortage of human capital and brain drain. Due to disadvantages regarding income level and working and living environments, high level professionals tend to work in eastern coastal regions rather than western regions. More than 90 percent of college and university graduates in Western China prefer to obtain employment in eastern regions (He, 2008).

Rural labor force drain in Western China is also remarkable. Since the late 1980s, large numbers of peasants began to leave their homes and seek work in cities. The number of these "Rural Migrant Workers" reached 154.33 million in 2009 (referring to rural migrant workers who move to another province), of whom $31.6 \%$ were from Western China. Of Western China's rural migrant workers, $59.1 \%$ of them moved outside their provinces to other regions, often eastern regions. More importantly, most of the outgoing rural migrant workers are young, strong and relatively better educated peasants, while the remaining workers who did not leave the region include many sick, old and poorly educated people (NBS, 2010). Obviously, this rural labor force drain may have a negative impact on Western China's rural economy, especially in the areas of agriculture development and national food security.

\section{Backward Technology and Innovation Capability}

Technology progress is the source of long-term economic growth as it not only improves factor productivity, but also contributes to optimizing industrial structure. While conversely, economic development also promotes technology progress. Generally, a higher technical level in a region indicates a higher level of economic development. The problem is that both technology and economic development levels of Western China are very low. Recent studies show that TFP (Total Factor Productivity) contribution to growth in Western China was much lower than that in other regions (Jefferson, $\mathrm{Hu}$ and $\mathrm{Su}, 2006$; Li, 2009). 
Table no.4

R\&D Expenditure Level of Western China

\begin{tabular}{|c|c|c|c|c|c|c|c|c|c|c|c|c|}
\hline & 1998 & 1999 & 2000 & 2001 & 2002 & 2003 & 2004 & 2005 & 2006 & 2007 & 2008 & 2009 \\
\hline \multicolumn{13}{|c|}{ R\&D Expenditure Share in GDP $(\%)$} \\
\hline Western China & 0.57 & 0.62 & 0.82 & & & & & & & & & 1.08 \\
\hline & & & & & & & & & & & & \\
\hline & & & & & & & & & & & & 18 \\
\hline & & & & & & & & 1. & & & & .36 \\
\hline National & 0.58 & 0.68 & 0.91 & 0.96 & 1.07 & 1.12 & & & & & & 1.59 \\
\hline \multicolumn{13}{|c|}{ nditure Share in National Total R\&D Expenditure (\%) } \\
\hline Easter & 59.42 & 61.38 & & 63.79 & & 64.75 & 66.97 & 67.31 & & & 67.97 & 65.84 \\
\hline & & & & & & & & 11. & & & & 14.38 \\
\hline & 17. & 16.3 & 15.7 & & & & & & & & & 12.49 \\
\hline Northeastern China & 9.92 & 8.71 & 7.82 & 8.68 & 9.35 & 9.18 & 9.04 & 8.69 & 7.78 & 7.61 & 7.14 & 7.29 \\
\hline
\end{tabular}

Note: The shares are calculated by authors based on R\&D expenditure (current prices) of every regions, National total value is the summation of provincial value. The Data are from various issues of China Statistical Yearbook on Science and Technology (Ministry of Science and Technology of National Bureau of Statistics, Various Issues).

As a key driver of technology progress, $R \& D$ expenditures for Western China increased significantly in the past decade. Even so, its shares of both GDP and national R\&D total spending are the lowest in the country, and the share in national total expenditures decreased annually after the implementation of WDS. For intra-regions of Western China, R\&D shares of Sichuan, Shaanxi and Chongqing remain some distance ahead of the other regions, and R\&D shares of Inner Mongolia and Guangxi increased sharply in recent years while other regions had smaller proportions.

To improve the level of technology, western regions need to enhance their capabilities for innovation. Although the innovation capability of Western China in general is much weaker than that of Eastern and Central China, the economic benefit derived from its innovation capability is not too bad: even better than that in Central China. The capability for innovation of Sichuan and Shaanxi province is stronger than that in most regions in Central China and also stronger than certain regions in Eastern China (Liu and $\mathrm{Hu}, 2002$ ). Therefore, building up a better innovation environment in all of western regions will be an effective solution for promoting technology progress and will eventually result in the upgrading of industrial structure.

\section{Industry Development and Ecological Environment}

Western China is now in the stage of a rapid industrial restructuring, where certain pressing issues need to be addressed seriously. First, contributions of industrial and service sectors to employment are very low although they obtained a very high value-added share in GDP, over half of the labor force is still employed by primary industry. Second, western regions primarily focused on resource-intensive and labor-intensive industries resulting in a slow growth of high-tech and emerging industries. Finally, there is extreme uneven distribution of industries in western regions, where most industries are located in Sichuan, Shaanxi and Guangxi province. Other regions have not yet found appropriate leading industries with comparative advantages. Moreover, underdeveloped service industries, especially producer services such as logistics and financial industries, cannot match the rapid growth of manufacturing industry.

Inefficient resource development resulted in serious resource waste and environmental damage. This is due to backward technology, lack of scientific planning and over-exploitation. Thus, the ecological environment in Western China deteriorated rapidly especially during the 1990s. Since the late 1990s, the government implemented several effective projects such as "Return Grain Plots to Forests", "Protection of Natural Forests", "Soil and Water Conservation" and other projects. These projects slowed down the environmental deterioration in recent years. However, the situation of "partial improvement and overall deterioration" still needs to be addressed. Studies show that soil 
erosion areas in Western China currently accounted for more than $80 \%$ of the nation's total and the area of desertification accounted for over $90 \%$ (Liu, 2011). The deterioration of ecological environment may have contributed to some natural disasters and also resulted in huge economic losses. If the exploitation of resources remains in its inefficient, high waste and high damage pattern, a fragile ecological environment will be a significant constraint on sustainable development in western areas.

\section{Conclusions and Prospects}

Based on the above statistical description and analysis of various economic indicators, we find that Western China's economic development underwent a dramatic reversal after the implementation of WDS, implying that, to some extent, WDS played a significant role in promoting the economic development of western regions. Economic performance in the past decade demonstrates that West China has entered a period of rapid and stable development, where gradually improved infrastructure and the increase in key preferential policies provides basic supports for future development. Even so, usual strategy upgrading is necessary for western development in the next stage.

The policy framework should be appropriately updated first. Promoting policies to western regions are supposed to match local conditions, taking into account the differences in natural and geographical environments as well as economic bases and comparative advantages. The present unified policies employed in different western regions may prevent the development of their own economies in the light of local conditions. Actually, learning from the practice of European Union, we can formulate different policies for different regions according to local conditions. For example, Western China can be divided into several territorial zones according to levels of economic development and different development policies to each zone may be appropriate.

As far as fiscal policies are concerned, we believe that three aspects need to be strengthened. First of all, the central government must unceasingly increase transfers to local governments in Western China so as to narrow the financial strength gap and further equalize the levels of public service. In fact, transfer payments used to adjust local governments' financial strength are very limited in China. Generally, 30\%-40\% of local governments' fiscal revenues are from their higher levels of government's financial transfers in developed countries. However, in China the ratio of general transfers from the central government to total local government revenues was $18.14 \%$ in 2010 , and dedicated transfers used to equalize local governments' financial strength was only $6.52 \%$ of the total local government revenues (MOF, 2011). Local governments' financial strength can also be enhanced through increasing their proportion of shared taxes (central and local government shares with fixed rate, for instance, $75 \%$ of value-added tax is now for the central government and $25 \%$ for local ones).

Tax preferential policy played a key role in WDS, yet the range of beneficiaries was not as wide as it should be. An investigative report revealed that enterprises benefitted from tax preferential policy of WDS accounted for less than 5\%. If enterprises enjoying special tax preference were excluded, actual beneficiaries were less than 2\% (Zhou et al, 2009). Obviously, it is very important to lower the entrance benchmark for preferential policy and allow more companies to receive the benefits. In addition, the present value-added tax (VAT) system in Western China needs to be reformed. In 2004 a pilot program was initiated in Northeastern China whereby consumption VAT substituted for production VAT. In 2007 this program was extended to Central China. VAT reform has greatly stimulated the technological updating, industrial restructuring and the development of industrial clusters in these regions. However, at present production VAT is still in effect in Western China.

Finally, as for policies concerning resource development and environmental protection, the most urgent task is to reform the existing resource tax and development pattern. Currently, the 
resource tax rate is very low (for example, real tax rate imposed on petroleum and gas is less than $5 \%$ ), which is definitely not conducive to energy saving and environmental protection. Therefore, the tax rate should not only be increased appropriately but it should also be diversified according to degrees of threats to local environments. In regions where the environment has been severely damaged due to inappropriate resource development, the tax must be imposed at a higher rate, and resource tax revenues should be mainly used primarily for local environmental protection.

\section{References}

1. Aziz J., Cui L., 2007. Explaining China's Low Consumption: The Neglected Role of Household Income, IMF Working Paper 07/181, available online at http://www.imf.org/external/pubs/ft/wp/2007/wp07181.pdf

2. Démurger S., 2001. Infrastructure Development and Economic growth: An Explanation for Regional Disparities in China, Journal of Comparative Economics, 29, pp.95-117.

3. Fan C.C., Sun M., 2008. Regional Inequality in China, 1978-2006, Eurasian geography and Economics, 49, pp.1-20.

4. Fan S., Kanbur R., Zhang X., 2010. China's Regional Disparities: Experience and Policy, Department of Applied Economics and Management Working Paper 2010-03, Cornell University, available online at http://kanbur.dyson.cornell.edu/papers/FanKanburZhangLimPaper.pdf

5. Graham E. M., Wada E., 2001. Foreign Direct Investment in China: Effects on Growth and Economic Performance. In P. Drysdale (ed), Achieving High Growth: Experience of Transition Economies in East Asia, Sydney, Oxford University Press

6. Gao X., Tong C., 2008. Gradual Evolution of China's Regional Policies Over the Past Three Decades, Tribune of Study, 24(12), pp.41-45.[Chinese Paper]

7. Golley J., 2007. China's Western Development Strategy and Nature versus Nurture, Journal of Chinese Economic and Business Studies, 5, pp.115-129.

8. Guo T., Lu D., Gan G., 2002. China's Regional Development Policy and Its Sound Effects on the Economic Development of Coastal Zones and Central \& Western Areas over the Past Two Decades, Geographical Research, 21(4), pp.504-509.[Chinese Paper]

9. Guo K., N'Diaye P., 2010. Determinants of China's Private Consumption: An International Perspective, IMF Working Paper 10/93, available online at http://www.imf-ieo.org/external/pubs/ft/wp/2010/wp1093.pdf.

10. He Y., 2008. The Employment Preference of Graduates in the Segmented Labor Market, Finance \& Economics, 52(9), pp.116-123.[Chinese Paper]

11. Jefferson G. H., Hu G. Z., Su J., 2006. The Sources and Sustainability of China's Economic Growth, Brooking Papers on Economic Activity, 2006(2), pp. 1-47.

12. Ke S., 2010. Effects of Urban Growth Poles on Economic Development in Central and Western China, Geographical Research, 29(3), pp.521-534.[Chinese Paper]

13. Ke S., Feser E., 2010. Count on the Growth Pole Strategy for Regional Economic Growth? Spread-Backwash Effects in Greater Central China, Regional Studies, 44(9), pp.1131-1147.

14. Li K., 2009. China's Total Factor Productivity Estimates by Region, Investment Sources and Ownership, Economic Systems, 33(3), pp.213-230.

15. Liu X., Hu Z., 2002. The Pattern of China Regional Innovation Capability and Its Implication, Studies in Science of Science, 20(5), pp.550-556.[Chinese Paper]

16. Liu Y., 2011. Development of the Western Region and the Great-leap-forward Development of Xinjiang, Beijing, Social Science Academic Press. [Chinese Book]

17. Liu S., Zhang X., 2007. The Features of China's Sustained High Growth and the Decline of Regional Economic Disparity, Economic Research Journal, 53(10), pp.17-31. .[Chinese Paper] 
18. MOF (China Ministry of Finance), 2011. National Financial Accounts 2010, Financial Data of Budget Department, http://yss.mof.gov.cn/.[Chinese Report]

19. RSD (Rural Survey Department of China National Bureau of Statistics), various versions. Poverty Monitoring Report of Rural China. Beijing, China Statistics Press. [Chinese Book]

20. SIC (China State Information Center), 2005. Extraordinary five years: the Five - years Progress of Western Development Strategy. Special Report of Five - years Western Development, http://www.chinawest.gov.cn/.[Chinese Report]

21. NBS (Rural Survey Department of China National Bureau of Statistics), 2010. Monitoring and Survey Report for Rural Migration Workers in 2009, Statistical Analysis Report, 2010-03-19, http://www.stats.gov.cn/.[Chinese Report]

22. Whalley J., Xin X., 2010. China's FDI and non-FDI economies and the sustainability of future high Chinese growth, China Economic Review, 21, pp.123-135.

23. Ye X., 2006. China Increases Western Development Investment, People's Daily Overseas Edition, 2006-09-06, p.04.

24. Zhou G., et al., 2009. Tax Preferential Policies of Western Development Strategy: What Shall It Do?, West Times, 2009-7-10, p.B2. [Chinese Newspaper article] 